\title{
HORMONAL MEASUREMENT IN RAT ANTERIOR PITUITARY CELL CULTURES: LOSS OF IMMUNOREACTIVE LH COUNTERACTED BY FETAL CALF SERUM AND BACITRACIN *
}

\author{
Ruth T. SAVOY-MOORE **, Thomas D. LANDEFELD and \\ John C. MARSHALL *** \\ Division of Endocrinology and Metabolism, Department of Internal Medicine, and the \\ Reproductive Endocrinology Program, Department of Pathology, The University of Michigan, \\ Ann Arbor, MI 48109 (U.S.A.)
}

Received 12 September 1979; accepted 2 January 1980

Immunoassayable LH in media samples from rat anterior pituitary cell cultures declines during storage and only $20 \%$ of the $\mathrm{LH}$ remains after 4 weeks at $-20^{\circ} \mathrm{C}$. The $\mathrm{LH}$ loss was not due to bacterial contamination or to damage to the hormone from repeated freezing and thawing. SDS-PAGE of ${ }^{125} \mathrm{IrLH}$ in media samples showed greater recovery of ${ }^{125} \mathrm{IrLH}$ when $1 \mathrm{mM}$ bacitracin or $2 \%$ fetal calf serum were present in the medium. The ratio of intact: subunit ${ }^{125}$ IrLH was unchanged by the presence of bacitracin or fetal calf serum indicating that the loss of immunoreactive LH was not due to dissociation of intact hormone. LH appears to be irreversibly altered in stored culture media, a process which can be prevented by the addition of bacitracin or fetal calf serum to the media prior to storage. The use of either substance allows accurate and reproducible measurement of $\mathrm{LH}$ released from pituitary cells in culture.

Keywords: $\mathrm{rLH}$ destruction; immunoassayable $\mathrm{rLH}$; SDS-PAGE of $\mathrm{rLH}$; $\mathrm{rLH}$ storage losses.

The enzymatically dispersed pituitary cell culture method (Portanova et al., 1970 ) has proven to be a powerful tool in the investigation of anterior pituitary function. Numerous investigators have reported that gonadotropin-releasing hormone (GnRH) stimulates release of luteinizing hormone (LH) and follicle-stimulating hormone (FSH) from cultured pituitary cells (Vale et al., 1972; Labrie et al., 1973; Tang and Spies, 1975, 1976; Lloyd and McShan, 1976; Drouin et al., 1976;

\footnotetext{
* A preliminary report was presented at the 63rd Annual F.A.S.E.B. meetings, April, 1979, Abstract 3995. Supported in part by grants from The University of Michigan and NIH, HD 11489 and T32-AM 07245.

** NRSA Postdoctoral Trainee, Division of Endocrinology and Metabolism. Current address: Department of Biological Sciences, Hogan Hall, Northwestern University, Evanston, IL 60201 (U.S.A.)

*** To whom reprint requests should be addressed.
} 
Hopkins and Gregory, 1977; Miller et al., 1977; Azhar et al., 1978). While investigating the secretory dynamics of $\mathrm{LH}$ release from rat anterior pituitary cells, we discovered that immunologically measurable LH in culture media was being lost during storage at $-20^{\circ}$. Such loss of end-product can greatly alter interpretation of experimental results and precludes reassay of the media samples. To insure accurate representation of the responsiveness of cell cultures, the experiments described in this article were undertaken to document the LH loss and to investigate preventative measures.

\section{MATERIALS AND METHODS}

\section{Cell dissociation and culture}

The dissociated anterior pituitary cell culture method of Vale et al. (1972) was modified as follows. Anterior pituitaries are removed from adult female rats (200$225 \mathrm{~g}$, Spartan) and rinsed 4-6 times in room-temperature sterile hepes-balanced salt buffer. The pituitaries are minced into $1-2 \mathrm{~mm}$ pieces, rinsed a further 3-4 times, and then subjected to a 2-stage enzymatic dispersion by collagenase (1.4 $\mathrm{mg} / \mathrm{ml}$, CLS II, Worthington), followed by pancreatin $(0.025 \%$, Gibco). A ratio of 1 pituitary to $1 \mathrm{ml}$ enzymatic buffer is used. Every $10 \mathrm{~min}$, the suspension is vigorously pipeted with a siliconized pasteur for $5 \mathrm{~min}$. When the yield reaches $10^{6}$ cells/pituitary, the suspension is centrifuged at $250 \mathrm{~g}$ for $5 \mathrm{~min}$. The pellet is washed 4 times with Dulbecco's modified Eagle's medium (DMEM, Gibco) containing $10 \%$ fetal calf serum (FCS, Flow), $100 \mathrm{U} / \mathrm{ml}$ penicillin and $100 \mathrm{U} / \mathrm{ml}$ streptomy. cin. Trypan blue exclusion is not used to check viability, since the validity of this test in the presence of exogenous protein is doubtful (Simmons et al., 1976). Cells are suspended in the culture medium (as above) at a concentration of 225000 cells $/ 2 \mathrm{ml}$ culture medium. The suspension is plated into Corning culture dishes $(35 \times 10 \mathrm{~mm})$ with a Cornwall repeating syringe $(2 \mathrm{ml})$. Cultures are maintained in a humidified atmosphere of $5 \% \mathrm{CO}_{2}$ and $95 \%$ air at $38^{\circ}$. Culture media is renewed after $48 \mathrm{~h}$.

Prior to the GnRH challenge ( $96 \mathrm{~h}$ after dissociation), the cells are washed once with fresh DMEM, then incubated in DMEM (no FCS). 90-95\% of the plated cells remain attached to the dishes at this point. Triplicate dishes are exposed to $10^{-11} \mathrm{M}$ to $5 \times 10^{-8} \mathrm{M} \mathrm{GnRH}$ (Hoechst) as well as DMEM alone (basal release; controls). After $4 \mathrm{~h}$, the media is transferred from the plates to $12 \times 75 \mathrm{~mm}$ culture tubes, centrifuged to remove cells, and the supernatant stored at $-20^{\circ}$ for later assay.

\section{LH assay}

LH was measured by o-o-rLH radioimmunoassay (RIA) (Niswender et al., 1968) using LH RP.1 as standard with a $24 \mathrm{~h}: 24 \mathrm{~h}: 24 \mathrm{~h}$ (antisera : tracer : second antibody) incubation. DMEM, GnRH and other test substances were included in all assays at the appropriate volumes and concentrations to exclude the possibility of interference in the assay. During the sequential study on LH loss, the inter-assay 
and intra-assay coefficients of variation (CV) were determined from 5 standard sera which were included 3 or more times in each LH assay.

Sodium dodecyl sulfate-polyacrylamide gel electrophoresis (SDS-PAGE)

To examine the integrity of $\mathrm{LH}$, samples to which iodinated rat $\mathrm{LH}\left({ }^{125} \mathrm{IrLH}\right)$ had been added were subjected to SDS-PAGE. A known amount of ${ }^{125}$ IrLH $(6 \times$ $10^{5} \mathrm{dpm} ; \sim 1 \mathrm{ng}$ ) was added to media previously unexposed to cells (fresh media) from cell incubations, both with and without inhibitors. Prior to analysis, samples were stored for at least $72 \mathrm{~h}$ at $4^{\circ}$ or $-20^{\circ}$.

Polyacrylamide electrophoresis was performed according to the method of Laemmli $(1970)$ in $15 \%$ gels $(15 \times 15 \times 0.15 \mathrm{~cm})$ containing $0.1 \%$ SDS. Protein samples were prepared at concentrations of $0.5-1.0 \mathrm{mg} / \mathrm{ml}$ in sample buffer consisting of $0.05 \mathrm{M} \mathrm{Tris}-\mathrm{HCl} \mathrm{pH} \mathrm{7.5,1 \%} \mathrm{SDS,} 10 \%$ glycerol and a trace of bromophenol blue.

The electrophoresis was conducted at a constant $150 \mathrm{~V}$ until the dye reached the front $(5-6 \mathrm{~h})$. The gel was stained in $0.2 \%$ Coomassie blue for $30-60 \mathrm{~min}$ and destained in $10 \%$ methanol-7.5\% acetic acid. The proteins were examined by autoradiography using Kodak XR5 film, exposed for $72 \mathrm{~h}$. The X-ray was utilized as a guide to obtain radioactive gel slices. Care was taken to insure that all gel cuts were the same height in the assay tube during gamma counting. Background was subtracted prior to results being expressed as:

$\frac{\text { counts recovered from gel band }}{\text { counts applied to sample lane }}=\%$ of applied counts recovered

\section{Inhibitors}

Inhibitors were obtained from Sigma Chemical. The following final concentrations were utilized: trasylol, $13500 \mathrm{KIU} / \mathrm{ml}$ and bacitracin, $1 \mathrm{mM}$. Neither of these concentrations in fresh media cross-reacted in the LH assay.

\section{RESULTS}

\section{Loss of LH detected by RIA}

A dose-response curve of $\mathrm{LH}$ release in response to GnRH is shown in curve $\mathrm{A}$ of Fig. 1. These results were obtained by RIA begun 1 day after GnRH challenge, while the data shown in curve B was from a RIA of the same samples begun 14 days after $\mathrm{GnRH}$ challenge. Samples were stored at $-20^{\circ}$ between assays. The later assay results indicated lower $\mathrm{LH}$ values at all points on the dose-response curve. At the maximum response ( $\mathrm{GnRH}$ doses $5 \times 10^{-9} \mathrm{M}$ through $5 \times 10^{-8} \mathrm{M}$ ), LH levels (A values $-B$ values/A values) were decreased by $27.1 \%$. Since LH RIA variations (between assay CV, 16.7\%) could not explain the declining LH values, 3 other explanations were considered.

\section{Bacterial contamination}

To rule out bacterial degradation of $\mathrm{LH}$, the experiment was repeated but steril- 


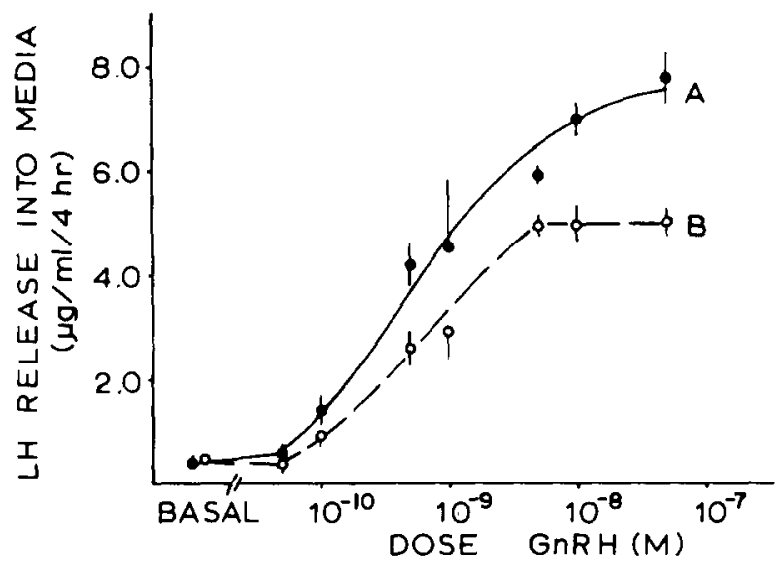

Fig. 1. LH release from cultured rat anterior pituitary cells in response to GnRH. Curve A represents results from a LH RIA performed within 1 week of $\mathrm{GnRH}$ challenge. Curve B shows the results from RIA of the same samples 2 weeks after $\mathrm{GnRH}$ challenge. Cultures contained $275000 \mathrm{cells} /$ dish; mean \pm S.E. of triplicate dishes are depicted.

ity was maintained throughout all procedures up to the LH assay. Aerobic and anaerobic culture of the media from cell incubations did not reveal bacterial growth and mycoplasma testing was negative. LH loss was still demonstrable in aliquots of the media after one week of storage at $-20^{\circ}$.

\section{Damage from freezing and thawing}

Samples from a dose-response experiment in which sterility was maintained were aliquoted and subjected to $0-3$ freeze/thaws before being pipeted into the RIA. Aliquots of the samples, assayed after 3, 2 or 1 thaw(s) over a 1 -month period demonstrated a similar loss of LH. Samples not frozen, or frozen and thawed within a few hours, showed equivalent LH values. Thus, damage induced by freezing and thawing could not account for the decline in LH values.

Despite these negative results, sterility was maintained up to RIA and samples were frozen and thawed as few times as possible during subsequent investigations.

\section{Enzymatic degradation of $L H$}

Several enzymatic inhibitors were utilized to examine the possibility that the loss of LH was due to proteolysis. Two enzymatic inhibitors, bacitracin and trasylol, and an exogenous protein source, FCS, were included in the incubation during GnRH challenge. The results of this experiment are shown in Fig. 2. The highest level of LH was measured when bacitracin or FCS were present. LH values measured in the presence of trasylol were no different than those measured in "media alone" samples.

To examine whether bacitracin and FCS would be effective at all dose ranges of 

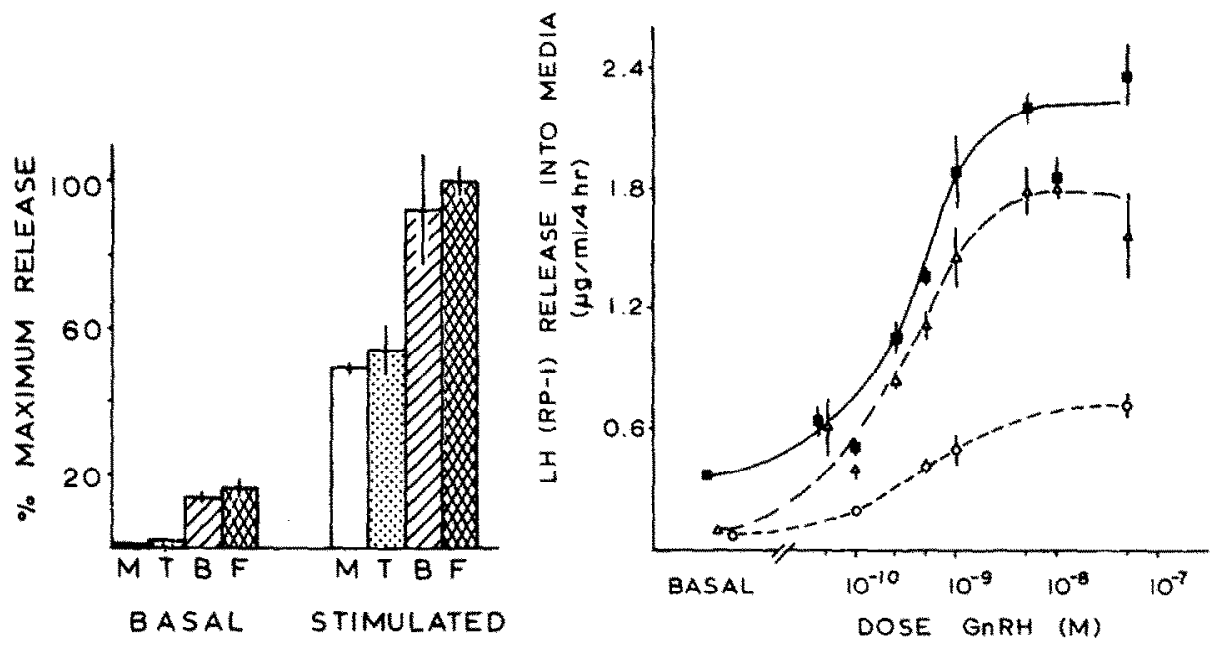

Fig. 2. Basal release of $L H$, and response to $\mathrm{GnRH}\left(10^{-8} \mathrm{M}\right)$ in the presence and absence of the inhibitors trasylol (dotted bars, T; $13500 \mathrm{KIU} / \mathrm{ml}$ ); bacitracin (slashed bars, B; $1 \mathrm{mM}$ ); fetal calf serum (hatched bars, F; $2 \%$ ); and media alone (open bars, M). Means \pm S.E. are shown.

Fig. 3. Effect on immunoreactive LH of cultures incubated with bacitracin ( $(\Delta)$ or media alone $(0)$. Cultures contained 190000 cells/dish; mean $\pm S$.E. of triplicate dishes are represented.

GnRH, both were included in the dose-response curves depicted in Fig. 3. The values of immunoassayable LH were higher when either the inhibitor or exogenous protein source was included during the 4 -h incubation with GnRH. To study the effectiveness of both substances on LH during longer storage, the experiment was repeated and selected samples were measured in 4 RIAs over a 6-week period. Samples were stored at $-20^{\circ}$ between assays. The results from 2 of these RIAs performed 6 and 31 days after the GnRH challenge are shown in Table 1. In media alone samples a loss of LC occurred between 6 and 31 days after GnRH stimula* tion. No detectable loss occurred over this period in samples from incubations containing bacitracin or FCS. Further, when aliquots of the "media alone" samples were stored in tubes containing bacitracin (1B-3B), media LH values were equivalent to those found when bacitracin or FCS was present during the incubation. Comparison of the two "media alone" aliquots (1-3 and $1 \mathrm{~B}-3 \mathrm{~B})$ indicates that a substantial loss of LH (approx. 60\%) had already occurred by the time of the first LH assay at 6 days. No further loss occurred between 31 days and 6 weeks of sample storage.

\section{$S D S-P A G E$}

In order to document $\mathrm{LH}$ degradation, the simplest experiment would involve adding a known amount of rat $\mathrm{LH}$ and following its disappearance from media previously exposed to cells. However, the amount of LH secreted by the GnRH-stimu- 


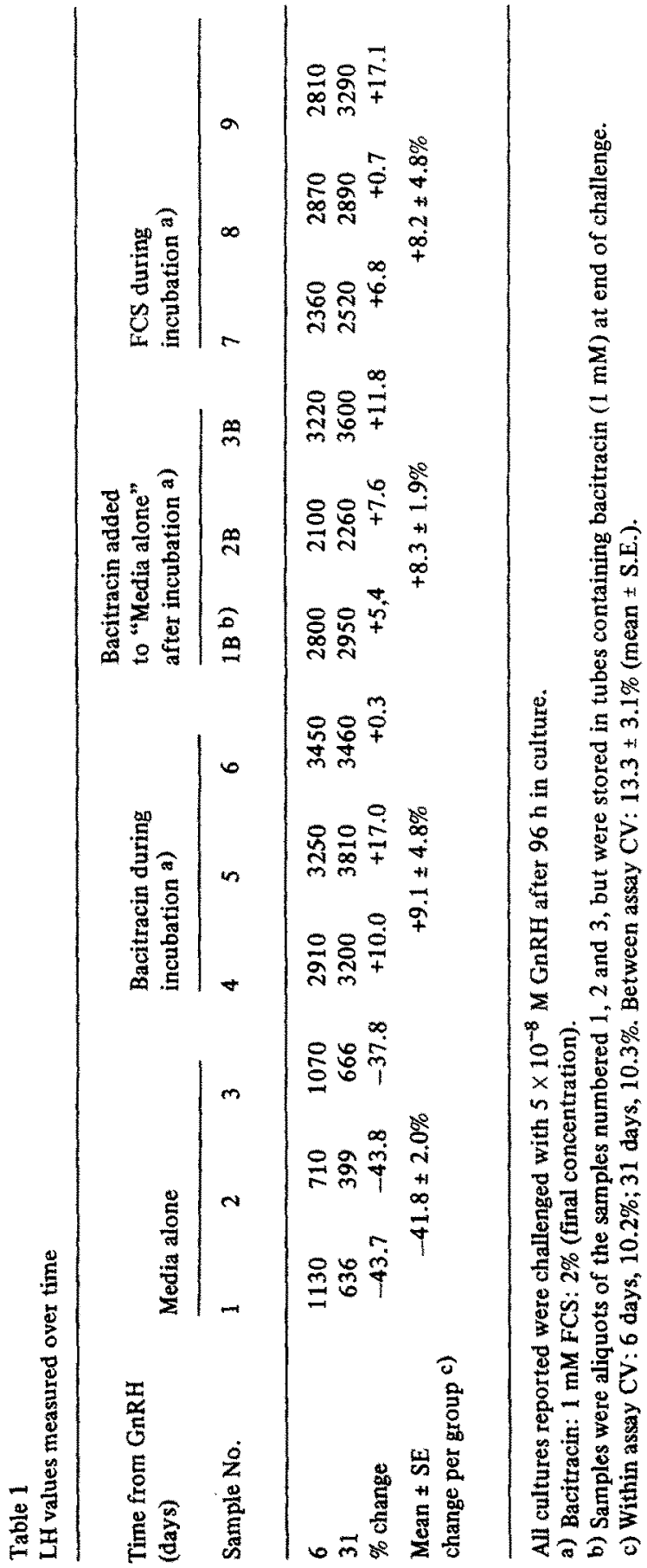


Table 2

SDS-PAGE of ${ }^{125} \mathrm{IrLH}$

\begin{tabular}{cll}
\hline & \multicolumn{2}{l}{ Percent of applied counts recovered a) } \\
\cline { 2 - 3 } & Intact LH band & Subunit LH band \\
\hline Fresh media & & \\
Media alone & $13.1 \pm 1.1$ & $43.3 \pm 5.0$ \\
Media + bacitracin & $14.4 \pm 1.4$ & $54.2 \pm 5.8$ \\
Media + FCS & $15.5 \pm 2.5$ & $56.4 \pm 6.4$ \\
Media from cell incubations & & \\
Basal & & \\
Media alone & $11.6 \pm 0.4$ & $21.9 \pm 4.2$ \\
Media + bacitracin & $20.1 \pm 1.9$ & $35.9 \pm 4.9$ \\
GnRH stimulated & & \\
Media alone & $11.8 \pm 1.8$ & $30.5 \pm 4.2$ \\
Media + bacitracin & $19.0 \pm 2.9$ & $40.8 \pm 4.6$ \\
Media + FCS & $17.5 \pm 1.3$ & $45.9 \pm 2.9$ \\
\hline
\end{tabular}

a) $125 \mathrm{IrLH}$ in media ( \pm FCS or bacitracin) electrophoresed on SDS-PAGE. The figures shown are mean \pm S.E. (for two or more lanes) of the counts recovered in either the intact LH band or the subunit band, determined by cold marker proteins, expressed as a percentage of the total counts applied to the lane.

lated cells is already so high that milligram amounts of rat $\mathrm{LH}$ would be required to perform the experiment. We therefore utilized SDS-PAGE and ${ }^{125} \operatorname{IrLH}$ in an effort to examine LH integrity in media samples from cell cultures.

Samples from a variety of experimental conditions were incubated with ${ }^{125} \mathrm{IrLH}$, then subjected to analysis by SDS-PAGE. The identification of radioactive bands as intact LH or its subunits was confirmed by the corresponding movement of the marker proteins oLH, BSA and lysosyme. Results from the SDS-PAGE experiments are summarized in Table 2.

${ }^{125}$ IrLH in fresh media contained a small amount of intact $\mathrm{LH}$, but the majority of the hormone was seen as subunits, as previously reported by Gospodarowicz (1972). The mean subunit: intact $\mathrm{LH}$ ratio observed was $3.3: 1$. The addition of FCS or bacitracin to media not exposed to cells did not alter the subunit: intact ratio, nor result in a significantly greater recovery of either intact or subunit LH from the gel (Student's $t, p>0.05$ ).

Media from cell incubations, however, demonstrated a higher recovery of intact LH and of subunit when bacitracin or FCS was included $(p<0.05)$. There were no significant differences between samples containing either FCS or bacitracin. Total recovery of radioactivity (intact $\mathbf{L H}+$ subunit) from the gels was also significantly higher when either preventative was present [samples without inhibitor, $39.8 \pm$ $4.2 \%$ (mean \pm S.E.; $n=7$ ); with bacitracin, $57.9 \pm 4.5 \%(n=8)$; with $2 \%$ FCS, 


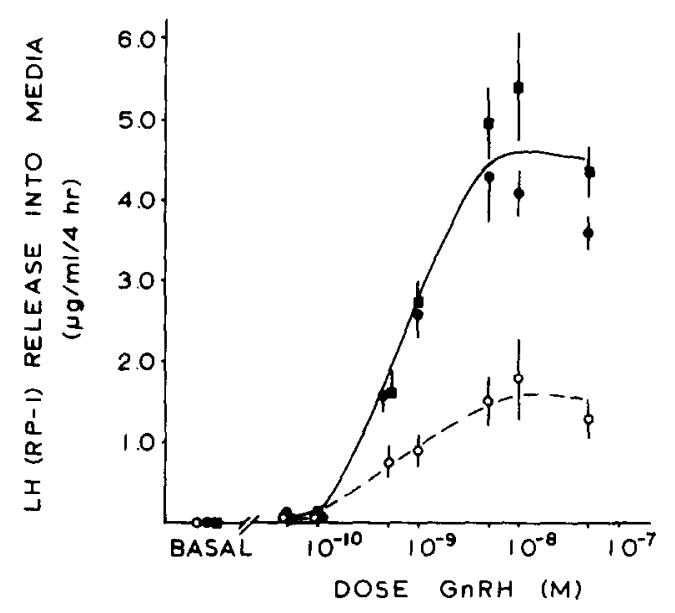

Fig. 4. Cumulative dose-response curves from 5 Expts. demonstrating the effectiveness of bacitracin in preventing LH loss when present during the incubation ( $\bullet$ ) or added to the media storage tube after $(\bullet)$ the incubation. Results represented by $0_{-}--0$ were from cultures which lacked inhibitor. Basal release was subtracted from each experiment prior to data combination. Cells/culture dish ranged from $175000-245000$; mean \pm S.E. are shown. All LH assays were begun within 8 days of GnRH challenge.

$65.4 \pm 3.3 \%(n=8)]$. In the absence of inhibitors, LH losses occurred which could not be demonstrated by radioactive bands of fragments smaller than the subunits. Under the conditions of the electrophoresis, small fragments may have migrated off the gel and hence were undetected.

\section{Resolution of LH loss}

The inclusion of either bacitracin or FCS prior to LH RIA prevents LH loss. The results of a series of experiments utilizing bacitracin either during the incubation or added to the media after the incubation are shown in Fig. 4. To compare values from different cultures, basal secretion has been subtracted in each experiment. As previously indicated, the inclusion of bacitracin results in a 3-fold increase in the amount of measurable $\mathrm{LH}$ released into the media in response to $\mathrm{GnRH}$.

\section{DISCUSSION}

Our initial experiments with rat anterior pituitary cell cultures indicated that cell responsiveness could not be reliably assessed when media samples were repeatedly assayed for LH. During storage at $-20^{\circ}$, there was an irreversible loss of immunoassayable LH from media obtained under experimental conditions. LH loss still occurred despite precautions against exogenous bacterial contamination and damage by freezing and thawing. We were left with the possibility that an enzyme, 
released from pituitary cells, could be responsible for the observed LH losses.

Pituitary cells are known to contain enzymes capable of degrading GnRH (Koch et al., 1974), but data on gonadotropins are lacking. The work of Freychet et al. (1972) on proinsulin degradation, and of Gordon et al. (1978) on insulin breakdown led us to employ the enzymatic inhibitors trasylol and bacitracin. We speculated that the enzyme may not normally degrade LH, but could do so in the absence of normal substrate. Thus fetal calf serum, often excluded from cultures during GnRH challenge, was incorporated to provide a rich source of other proteins. Both bacitracin and fetal calf serum have proven to be effective in preventing LH losses over time.

To conclusively demonstrate that an enzyme was responsible for LH loss, $\mathrm{LH}$ degradation products must be determined. SDS-PAGE of media exposed to cells failed to show any bands smaller than LH subunits, so we cannot be certain that the LH is degraded. However, the SDS-PAGE results confirmed the physical loss of LH previously detected by RIA. Since the LH intact: subunit ratio was unchanged in the presence of bacitracin or FCS, the higher LH measured by RIA was not due to increased dissociation into subunits. Recently, Loeber et al. (1978) reported that highly purified human LH will dissociate into subunits at temperatures above $4^{\circ}$, and that neither trasylol nor a variety of other inhibitors prevented the reaction. In our experiments, bacitracin and fetal calf serum appear to have protected the rat LH from a process other than dissociation.

It is extremely important to circumvent $\mathrm{LH}$ losses from pituitary cell culture media. Our results indicate that substantial losses can occur within days of the GnRH challenge (Table 1, samples $1 \mathrm{~B}-3 \mathrm{~B}$ vs. $1-3$ ). Without preventative measures, the time lapse between culture and LH immunoassay could become a major variable in experimental results. Appropriate precautions maintain LH values that are reproducible over repeated $\mathrm{LH}$ assays and that accurately reflect the responsiveness of the culture. Both FCS and bacitracin are effective for this purpose. The unknown stcroid content of commercially available FCS would indicate that charcoal extraction is necessary prior to use in experimental incubations performed to assess gonadotropin release. Alternatively, bacitracin can be added to the media storage tube immediately following the incubation and need not be present during the experiment. It is inexpensive, and effective at a final concentration of $0.1 \mathrm{mM}$, although we routinely emply it at $1 \mathrm{mM}$. As demonstrated, measured LH in samples with bacitracin can be 3-fold higher than values from cultures without inhibitor. We have not yet assessed whether other hormones secreted by cultured pituitary cells, particularly follicle-stimulating hormone and prolactin, may be subjected to similar destruction during storage. It would seem important for other investigators utilizing these systems to determine whether the hormone of interest is stable during storage. 


\section{ACKNOWLEDGEMENTS}

The authors gratefully acknowledge the members of the Reproductive Endocrinology Program who provided facilities and reagents for LH RIA and SDS-PAGE, and for their intellectual criticism of these experiments.

\section{REFERENCES}

Azhar, S., Reel, J.R., Pastushok, C.A., and Menon, K.M.J. (1978) Biochem. Biophys. Res. Commun. 80, 659-666.

Drouin, J., Lagacé, L., and Labrie, F. (1976) Endocrinology 99, 1477-1481.

Freychet, P., Kahn, R., Roth, J., and Neville Jr., D.M. (1972) J. Biol. Chem. 247, 3953-3961.

Gordon, P., Carpenter, J.-L., Freychet, P., Le Cam, A., and Orci, L. (1978) Science 200, 782785.

Gospodarowicz, D. (1972) Endocrinology 90, 1101-1104.

Hopkins, C.R., and Gregory, H. (1977) J. Cell Biol. 75, 528-540.

Koch, Y., Baram, T., and Chobsieng, P. (1974) Biochem. Biophys. Res. Commun. 61, 95-103.

Labrie, F., Pelletier, G., Lemay, A., Borgeat, P., Bardin, N., Dupont, A., Savary, M., Côté, J., and Boucher, R., (1973) Acta Endocrinol. (Copenhagen) Suppl. 180, 301-340.

Laemmli, U.K. (1970) Nature (London) 227, 680-685.

Lloyd, R.V. and McShan, W.H. (1976) Proc. Soc. Exp. Biol. Med. 151, 160-162.

Loeber, J.G., Nabben-Fleuren, J.W.G.M., Elvers, L.H., Segers, M.F.G., and Lequin, R.M. (1978) Endocrinology 103, 2240-2246.

Miller, W.L., Knight, M.M., Grimek, H.J., and Gorski, J. (1977) Endocrinology 100, 13061316.

Niswender, G.D., Midgley, Jr. A.R., Monroe, S.E., and Reichert Jr., L.E. (1968) Proc. Soc. Exp. Biol. Med. 128, 807-811.

Portanova, R., Smith, D.K., and Sayers, G. (1970) Proc. Soc. Fxp. Biol. Med. 133, 573-576.

Simmons, K.R., Caffrey, J.L., Phillips, J.L., Abel Jr., J.H. and Niswender, G.D. (1976) Proc. Soc. Exp. Biol. Med. 152, 366-371.

Tang, L.K.L., and Spies, H.G. (1975) Endocrinology 96, 349-356.

Tang, L.K.L., and Spies, H.G. (1976) Proc. Soc. Exp. Biol. Med. 151, 189-192.

Vale, W., Grant, G., Amoss, M., Blackwell, R., and Guillemin, R. (1972) Endocrinology 91, 562-572. 